\title{
HONVÉDELEM
}

Fórizs Sándor^

\section{A Honvéd Határórség hivatásos állományának eltávolítása az ÁVH Határőrség szervezetéból}

DOI 10.17047/HADTUD.2021.31.2.107

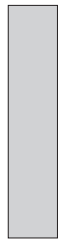

\begin{abstract}
A Honvéd Határơrség 1950. január elsejével az Államvédelmi Hatóság Határőrség szervezetébe került a Magyar Honvédségtól. A szerző levéltári kutatások alapján bemutatja, hogy az átszervezés során rövid idôn belül eltávolították a hivatásos állomány jelentôs részét, kiemelten a vezetés területén dolgozókat. A tanulmányból az olvasó megismerheti az elbocsájtások részletes adatait, a személyi állomány pótlásának módszereit, a régi és az új állomány szociális összetételét.
\end{abstract}

KULCSSZAVAK: határőrség, tiszt, tiszthelyettes, leszerelés, elbocsájtás

\section{The Removal of the Professional Personnel of the Former Honvéd Border Guard (of the Hungarian Army) from the Organisation of the Hungarian State Security Authority (Államvédelmi Hatóság, ÁVH) Border Guard}

On $1^{\text {st }}$ January 1950, the Border Guard of the Hungarian Army was removed from the Hungarian Defence Forces and was integrated into the State Security Authority Border Guard. Based on archival research, the author presents that a significant part of the professional personnel, especially those working in the headquarters, was removed shortly after the reorganisation. The paper discusses the details of the dismissals, the methods of replacing the personnel and the social composition of the old and the new personnel.

KEYWORDS: Border Guard, commissioned officer, non-commissioned officer, demobilisation, dismissal

\section{Bevezetés}

A Honvéd Határớrséget 1945 elején alapították. Az országos parancsnokságát 1946 márciusában hozták létre. A kötelék létrejöttének kezdetétól az akkori belpolitikai

Nemzeti Közszolgálati Egyetem -

National University of Public Service,

e-mail: forizs.sandor@uni-nke.hu; https://orcid.org/0000-0001-6019-3295 
harcok sodorvonalába került, a különbözó pártok mind szerették volna megszerezni a irányítást fölötte. Ezen nem is lehet csodálkozni, hiszen kezdeti 5000 fós, majd növekvô létszámával az akkori alig húszezer embert számláló honvédség mellett az ország második legnagyobb létszámú fegyveres szervezete volt. ${ }^{1}$

A minisztertanács 4.353/1949/268. M. T. számú rendelete 1950. január 1-tól a Honvéd Határôrséget leválasztotta a honvédségról, és az Államvédelmi Hatósághoz helyezte. Az ÁVH vezetójét a minisztertanács elóterjesztésére a Népköztársaság Elnöki Tanácsa nevezte ki. Első vezetóje Péter Gábor altábornagy lett, aki a határórséget a IV. Főosztály vezetójén keresztül (1950. január elsejétól Kajli József áv. ezredes) irányította. Már 1950. október 24-tól új vezetót kapott a határôrség Piros László személyében, aki, mint az ÁVH Határôrség és Belsó Karhatalom (fô)parancsnoka 1953. júliusáig tevékenykedett. Pályafutása során egyre magasabb beosztásokat töltött be, és 1954. július 6-tól belügyminiszter lett az'56. októberi eseményekig. A határórségre mindvégig jellemző volt a felsó- és középvezetók folyamatos, súrú változása, de az 1950-1951-es évek különösen tragikusnak bizonyultak a hivatásos állomány átszervezése terén.

Bizonyos értelemben az elójelek már 1949-ben jelentkeztek, és mutatták, az ország politikai vezetésének ugyan szüksége van a határôrségre, de nem annak vezető tagjaira. ${ }^{2}$ 1949. október 24-én, egyazon napon, koncepciós per alapján kivégezték Pálffy György altábornagyot, honvédelmi miniszterhelyettest, a határôrség elsó főparancsnokát (országos parancsnok), Németh Dezső ezredest, aki a határórség törzsfőnöke volt Pálffy mellett 1947-ben, és Korondi Béla őrnagyot, aki szintén vezető beosztást töltött be a határôrség parancsnokságán. Mindhárman egykori „ludovikás” tisztek, és ez már jelezte a késóbbi személyzeti munka vélhetô irányát.

A honvédelmi miniszter 1949. december 30-án kelt 17. sz. napiparancsa (55.372/eln. Min. Ir.-1949) rendelte el a szervezet átadását. Már a dátumok olvasásakor is láthatjuk, eróltetett, gyorsított átszervezésról volt szó, a megszabott rövid határidő átgondolt, módszeres átadást-átvételt nem tett lehetôvé.

Publikációmban az 1950-ben a honvédségtól átvett hivatásos állomány további sorsával kívánok foglalkozni a Magyar Nemzeti Levéltár Országos Levéltárában fellelhetô dokumentumok alapján.

\section{A személyzeti munka adatai}

A hivatásos állománnyal kapcsolatos eljárások a határórség nagyarányú átszervezéséhez kapcsolódnak. Erról pontos, megbízható adatokkal rendelkezünk, és betekinthetünk az azt mozgató elképzelésekbe. A Magyar Nemzeti Levéltár (a továbbiakban MNL) Országos Levéltára ôrzi a határórség országos parancsnoksága (HOP) fennmaradt dokumentumait. Ezek között található más vonatkozó okmányokkal együtt a „Jelentés a Határórség és Belső Karhatalom káderhelyzetéról. 1951. III. 5.-én”3

1 Fórizs 2015; Fórizs 2017.

2 Deák 2015.

3 MNL HOP XIX-B-10 9. sz. doboz 1951. II/2, II/3, II/5, II/6, II/9 tárgykör 1. folyószám, „Jelentés a Határôrség és Belső Karhatalom káderhelyzetéról. 1951 III. 5.-én" 
címzésú felterjesztés. Géppel ráírva Piros László áv. altábornagy az ÁVH Határôrség és Belsô Karhatalom parancsnoka, parancsnoksági fejrész található az elsô oldalon és az 1951. 03. 15. dátum.

A csatolt kíséró levélból kitúnik, hogy a Magyar Dolgozók Pártja (MDP) titkársága tárgyalni szándékozta a határôrség helyzetét, és a felterjesztés e célból készült. Címzett: „Földes László Elvtársnak, MDP Központi Vezetôsége Káderosztály.”4 Nem kisebb személy, mint Rákosi Mátyás érdeklődhetett a határôrség állapota iránt, amit az egyik mondat bizonyít: „A Rákosi Titkárság utasítására a jelentés két példányát ... megküldöm." A határôrség helyzetét mindig nemzetbiztonsági kérdésként kezelték. ${ }^{5}$

Értenünk kell az ekkor készített dokumentumok különbözô kifejezéseinek jelentését a hivatásos állománnyal kapcsolatban. A „régi”, illetve „új” tiszt a '45 elótti vagy utáni kinevezést jelentette, amely ekkor vízválasztóként szerepelt. Szinte hasonló a „hothysta” jelzó, és semmi köze ahhoz, hogy az illetô kompromittálta magát a háború során, részt vett-e zsidóüldözésben, fosztogatásban, bármilyen háborús búncselekményben. Tudnunk kell, a Honvéd Határórség hivatásos állománya, és nem beszélünk most a honvédelmi kötelezettség alapján szolgált sorállományról, ' 45 után jelentkezett az új, úgynevezett „demokratikus hadseregbe”, sokan tagjai voltak a vasút- és hídépító alakulatoknak, az Ausztriába kivonult, de a harcokról már lemaradt frissen felállított kötelékeknek. Lényegében olyan személyek, akik bizonyították elkötelezettségüket a beindult társadalmi változások mellett a megelôzó öt évben.

A határórségnek az átvételkor személyzeti szervezete nem volt, nyilvántartással az átvételkor nem rendelkezett, káderosztályt 1950. januárban állítottak fel egy fő vezetô és két fő munkatárs szervezésben. Elképzelhetô, mit tudtak ók tenni személyzeti ügyintézés vonatkozásában, amikor egy tízezer fő́t meghaladó szervezetet kellett két hónap alatt átszervezni. Ugyanekkor állították fel a Belsó Karhatalom káderosztályát és júliusban a Politikai Osztály káderalosztályát. Semmilyen kádertervvel nem rendelkeztek, a kiválasztás mindig ad hoc jellegú volt, személyzeti munkára nem volt hosszú távú elképzelés, azon kívül, hogy kiket kell kiszorítani a rendszerból. Ez nem saját vélemény, a jelentés tartalmazza.

A tisztogatás természetesen a vezető beosztásokkal kezdődött. „A Parancsnokságról eltávolítottunk 23 vezetót, 37 beosztottat. Az alakulatoktól Déli és Nyugati viszonylatban 27 vezetôt, 37 beosztottat, egyéb viszonylatban 24 vezetót, 21 beosztottat." ${ }^{6}$ Az országos parancsnokságon le lett váltva az összes régi horthysta osztályvezető, ezek helyére 17 fő került az ÁVH központjából, akik viszont határórizeti területen még nem dolgoztak, és szakmailag teljesen tájékozatlanok voltak, helyismerettel nem rendelkeztek.

4 Uo. Kísérô levél azonos nyilvántartási számon.

5 Deák 2016, 43-75.

6 MNL HOP XIX-B-10 9. sz. doboz 1951. II/2, II/3, II/5, II/6, II/9 tárgykör 1. folyószám, „Jelentés a Határőrség és Belső Karhatalom káderhelyzetéról. 1951. III. 5.-én" 


\section{Állománylétszámok}

Az állományban 1950. január elsején, tehát az átvétel napján, 481 fó tiszt teljesített szolgálatot, közülük 351 fő volt „régi” és 130 „új”. Tiszthelyettes 893 fő, régi 765 fő, új 128 fó. Az újak' 45 után lettek kinevezve. Az új tisztek között sokan voltak olyanok, akik a horthysta hadseregben tiszthelyettesként szolgáltak, majd a demokratikus hadseregben kinevezték óket tisztnek. Szociális származásuk szerint általában parasztok, gyakran nincstelen földmunkások, béresek, tehát elvileg meg kellett, hogy feleljenek az új politikai irányvonal igényeinek.

A határốrség hivatásos állománya 1951. 02. 01-én, tehát 13 hónappal az átvételt követốen, már másként nézett ki. Tiszt 997 fô, közülük régi 175 fő (közülük 96 fố régi tiszthelyettesból lett kinevezve tisztnek), új tiszt 822 fó.

1950. 01. 01. - 1951. 02. 01-ig eltávolítva a szervezetból:

- tiszt 218 fô, ebból régi 176 és új 42 fó;

- tiszthelyettesból eltávolítva 310 fő, ebból régi 256 fô és új 54 fô.

A megmaradt régi tisztek, összesen 175 fő beosztása a következő volt: az országos parancsnokságon osztályvezetô 1 fó, osztályvezetô-helyettes 3 fó, iskolaparancsnok 2 fó, beosztott tiszt 15 fó, összesen 21 fó; a csapatoknál kerületparancsnok (kerületi parancsnok, a kilenc közül) 1 fó, kerület törzsparancsnok 8 fó, kerület alosztályvezetô 18 fó, zászlóaljparancsnok 9 fô, egyéb beosztásban nem vezetố helyen 116 fô, összesen 154 fó.

Az 1951. februárra megmaradt régi tiszthelyettesek, 509 fó az alábbi beosztásokban dolgoztak:

- ớrsparancsnok Délen 20 fó, Nyugaton 9 fö, egyéb viszonylatban 57 fő, összesen 86 fö,

- ớrsparancsnok helyettes Délen 19 fó, Nyugaton 16 fö, egyéb viszonylatban 15 fó, összesen 50 fó;

- egyéb nem vezető beosztásban 373 fó.

A hivatásos állomány szociális megoszlása 1951. februárban az 1945 elótti foglalkozást figyelembe véve. ${ }^{8}$

A tiszti állomány:

- munkás 445 fó, nagyüzemi 284 fó, kisipari 161 fó;

- paraszt 262 fó, mezőgazdasági munkás 145 fő, szegényparaszt 116 fó;

- egyéb 290 fó, alkalmazott 114 fő, tisztviselő 3 fó, köztisztviselő 15 fő, értelmiségi 53 fő, kisiparos, kiskereskedő 4 fő, kulák, kapitalista 2 fó,

- foglalkozás nélküli, tanuló 99 fó.

A tiszthelyettes állomány szociális megoszlása:

- munkás 470 fó, nagyüzemi 201 fó, kisipari 269 fő;

- paraszt 494 fô, mezógazdasági munkás 452 fô, szegényparaszt 34 fô, középparaszt 8 fó,

7 Uo. I. sz. melléklet.

8 Uo. II. sz. melléklet. 
- egyéb 218 fó, alkalmazott 138 fó, értelmiségi 7 fő, kisiparos, kiskereskedő 11 fó, foglalkozás nélküli, iskolai tanuló 62 fó.

A tisztek pártállás szerinti megoszlása: összesen 997 tiszt, párttag 844 fó, ebból tagjelölt 44 fó, összesen 888 fó.

A tiszthelyettesek pártállás szerinti megoszlása: 1182 fő összesen, párttag 985 fó, ebból tagjelölt 83 fó, összesen 1068 fó.

Tisztek megoszlása rendfokozatok szerint: tábornok 1fó, ezredes 1fó, alezredes 8 fó, ốrnagy 33fó, fốtiszt összesen 43 fó; százados 91 fó, fóh adnagy 122 fó, hadnagy 123 fó, alhadnagy 618 fő; százados és beosztott tiszt 954 fô. Tiszt összesen 997 fớ. ${ }^{9}$

Tisztek katonai iskolai végzettsége:

- 3 hónapnál rövidebb tanfolyam 131 fó,

- 3-6 hónap tanfolyam 423 fó,

- 6 hónapnál hosszabb tanfolyam 211 fő,

- semmilyen katonai iskolája sincs 232 fó.

A felterjesztés lényegében keveréke egy politikai értékelésnek és a szakmai problémák felsorolásának. Mivel a politika elvárásai az elsődlegesek, a szakmai javaslatok már nem hozhatnak reális eredményt, hiszen nem mehetnek szembe a politika döntéseivel. Nézzük például a tiszthelyettes állományt ebból a szempontból. Az ôrsparancsnoki és oórsparancsnok helyettesi beosztások a határvadászoknál tiszthelyettesi munkakörök voltak. Északon és Keleten a húsz fós, Nyugaton és Délen a negyven fős alegységeket minden további nélkül elvezették a tiszthelyettesek. Az ô elbocsátásuk teljesen feleslegesen hirtelen megoldhatatlan tiszthiányt teremtett, nem beszélve a szakmai színvonal eséséról. De a domináló szempont nem a hozzáértés, hanem a régiektól történó megszabadulás volt. Meggyőződésem, hogy ezek a tiszthelyettesek, megfelelő egzisztenciális körülmények között, politikailag semmilyen veszélyt sem jelentettek volna a rendszerre. Ugyanez vonatkozik a beosztott tiszti állományra.

Az alábbi mondat mutatja, hol keresik a megoldást: a szervezet „tiszti és tiszthelyettesi állományának összetételében, minőségében bár van javulás, ami elsősorban a régi, horthysta, megbízhatatlan elemek eltávolításában, új fiatal munkás és dolgozó parasztkáderek beállításában mutatkozik meg" ${ }^{10}{ }^{10}$ Az aláhúzás a szerzô jelölése. Kérdés, miért lett volna egy tiszthelyettes órsparancsnok és tiszthelyettes helyettese megbízhatatlan mondjuk az Aggtelek határőr ôrsön?

A hivatalos megítélés szerint még viszonylag sok a régi káder. 175 régi tisztból nagy számban (44 fó) vannak komoly vezetó beosztásban A régi tiszthelyettesekból sokan órsparancsnokok, illetve helyettesek. A déli határon 77 örsparancsnokból 20 fő, Nyugaton 34-ból 9 fő régi tiszthelyettes.

Nem kielégító a szociális megoszlás. Csak a tisztek 44,6\%-a, a tiszthelyettesek 39,8\%-a munkás származású.

9 Uo. III. sz. melléklet.

10 MNL HOP XIX-B-10 9. sz. doboz 1951. II/2, II/3, II/5, II/6, II/9 tárgykör 1. folyószám, ,Jelentés a Határôrség és Belső Karhatalom káderhelyzetéról. 1951. III. 5.-én" 
A képzettségi problémákat is jól látják, csak azt nem írják le világosan, hogy azt az átszervezés módja teremtette.

- A határőrségnél 232 új tisztnek semmilyen katonai iskolája nincs, a 9 kerületparancsnokból 7 új tisztnek egy éves rendôr törzstiszti iskolája van.

- A politikai tisztek többsége elvégezte a 3, 6 vagy 8 hónapos Petófi Politikai Tisztképző Iskolát, ami persze határórizeti jellegú felkészítést nem adott. A legmagasabb katonai képzettség 1 éves honvédségi fegyvernemi iskola. Mindössze 4 fó végzett 1 éves törzstiszti tanfolyamot.

- „Komoly hiányunk van jelenleg törzsvezetésre, magasabb parancsnoki teendók ellátására alkalmas katonailag kiképzett tisztekben." 11

- Az új szervezet (állománytábla) szerint jelenleg tiszthiány a határốrségnél 416 fő. Mennyiségi és minőségi hiány van a tiszti állománynál. Az átvétel napján 481 fó tiszt volt a határvadászoknál. Alaposan fel lett bruttósítva a szervezet, és nagy érvágás volt az elbocsátás, ha '51. márciusban lényegében ugyanannyi a hiány, mint amennyi a kezdő létszám volt '50. januárban.

Vélemény a régi káderekról „A régi tisztek és tiszthelyettesek között bár nagy a párttagok aránya, azonban többségüknek a Párthoz való viszonya formális, jórészük egyéni érdekból lépett be a Pártba." ${ }^{12}$ Ezzel tulajdonképpen az elbocsátást kívánja indokolni és a maradás feltételévé a nehezen megfogható politikai azonosulást teszi a jelentô.

A pótlás megoldását a rohamlépésben zajló rövid idejú képzésben látja a határórség parancsnoka:

- 1951. áprilisban fejeződik be az elsố saját, 8 hónapos tiszti iskolai tanfolyam, 225 fốvel,

- a HM 1950-ben 2 éves különböző fegyvernemi tiszti iskolákra hívott be a polgári életból fiatalokat, ók '52-ben végeznek, a határőrség és a Belső Karhatalom 258 fő́t kap,

- egyéves fegyvernemi iskolán 257 fó tanul a két szervezethez, a Petốfi Politikai Tisztképző Iskolán 100 fő végzett 51-ben, akik a határórséghez, illetve a BK-hoz kerülnek,

- '51-ben végez még HM ezredparancsnoki tanfolyamon 12 fó, zászlóalj parancsnoki iskolán 30 fó, magasabb parancsnokin 1 fó,

- a helyzeten az javított, hogy a HM saját állományából 1950-ben átadott 253 tisztet, (ebból 91 fó politikai tiszt).

- 1950-ben a HM tiszti iskoláin végzett az oda vezényelt 300 fó.

Nyilvánvalóan nem egyszerú jelentkezóket találni, a határốrségnél rendkívül mostohák a szolgálati és életviszonyok. A határôrség a sorállomány köréból küldött tiszti képzésre katonákat. Rossz a káderkiválasztás, írják: „1950 októberében a Dózsa Gyalogostiszti Iskolára küldött 200 fő közül 46 fố az elsó hónap után azzal jött vissza, hogy nem tekinti élethivatásának a katonai pályát." 
„A most folyó minôsítés /felülvizsgálat/ befejezése után ... káderfejlesztési tervet kell készíteni." 1951. január negyedikével az országos parancsnok a teljes tiszthelyettesi állomány minősítését rendelte el, az intézkedés nyilvánvalóan összefüggött az elbocsátásokkal. A feladatot az úgynevezett „I. fokú bizottságok" végzik. ${ }^{13}$

„Meg kell javítani a tiszti és tiszthelyettesi állomány szociális összetételét, a munkások arányának növelésével." „Ez év május 1-ig a Déli és Nyugati határon minden régi tiszthelyettes órsparancsnokot le kell váltani, helyükbe a tiszti iskolát végzett órsparancsnokot kell kinevezni." ${ }^{14}$

Az anyag végén kilenc pontban tesznek javaslatot a helyzet ,javítására". A már említett politikai elsődlegesség miatt ezeknek lényegében nincs szakmai pozitívuma.

Az egyik, a tiszti iskola befejezése után szervezzenek tanfolyamot a tiszteknek. Amit lefordíthatunk úgy is, hogy elégtelen az iskolák határőr szakmai felkészítése, a képzést még meg kell "fejelni”.

Káder nyilvántartási rendszert szükséges készíteni, a kádermunkatársak számára egy kéthetes bentlakásos tanfolyamot kell szervezni, azaz továbbra is a személyzeti munka lenne a csodafegyver az elbocsátások leállítása helyett.

\section{Az elbocsátott állomány pótlása}

Az elbocsátások és a határôrségi állománytábla mértéktelen bôvítése hirtelen jelentôs hiányt támasztott a tiszthelyettesi és tiszti állomány terén. A probléma ellensúlyozására több megoldás is született.

Az ÁVH vezetôje 1951. 02. 01-én kelt 09/1951. ÁVH. T. biz. 9. sz. parancsában új állománycsoportot rendszeresített „államvédelmi polgári alkalmazott” megnevezéssel, „áv. pa." rövidítéssel. ${ }^{15}$ Tagjai a polgári státusz által megengedett munkaköröket láthattak el, nyilvánvalóan a kiszolgáló, biztosító feladatok területén. A határórizetben ténylegesen nem játszottak szerepet.

A Honvéd Határốrség ÁVH-hoz kerülését követôen, az ÁVH vezetốje 037/1951. ÁVH. T. Biz. 38. sz. parancsával 1951. 07. 01. hatállyal szakmailag teljesen érthetetlen okokból megszüntette a határơrségnél a hivatásos tiszthelyettesi állománykategóriát, és helyette a "továbbszolgáló tiszthelyettesi állományt" rendszeresítették. A tiszthelyettesek jelentôségét mutatja, hogy 1956 augusztusában 847 továbbszolgáló beosztás szerepelt az állománytáblázatban. Még az ekkor gyakran másolt szovjet katonai rendszernek is ellentmondott ez a megoldás, hiszen a szovjet fegyveres erók komoly hivatásos állományú tiszthelyettesi gárdával rendelkeztek. Az 1951-es intézkedés esetleg azzal magyarázható, hogy politikai megfontolásokból kívántak megszabadulni a hivatásos tiszthelyettesektól ezen az úton, mivel a határvadász tiszthelyettesek jelentős része korábban a Horthy hadseregben szolgált.

13 MNL HOP XIX-B-10 1951. év 1. sz. doboz. II/2, II/3, II/5, II/6, II/9 tárgykör 1. folyószám.

Államvédelmi Hatóság Határőrség és Belső Karhatalom Parancsnokának 01. sz. parancsa. 1951. 01.04. A tiszthelyettes állomány minősítése.

14 MNL HOP XIX-B-10 1951. év 9. sz. doboz II/2, II/3, II/5, II/6, II/9 tárgykör 1. folyószám, „Jelentés a Határoórség és Belső Karhatalom káderhelyzetéról. 1951. III. 5.-én"

15 MNL HOP XIX-B-10 1951. év 1. sz. doboz Államvédelmi Hatóság Határőrség és Belső Karhatalom Parancsnokának 019. sz. parancsa. Államvédelmi polgári alkalmazott állománycsoport létrehozása. 
Mindezek miatt a szervezet életéból, múködéséból/múködtetéséból hiányzott az a tartóoszlop, amely a tisztek távollétében a rendet biztosította volna, elsimítva az apró napi kérdéseket.

Csak jóval késóbb, 1957. 05. 20-án tesz javaslatot a határórség parancsnoka a belügyminiszternek egy hivatásos tiszthelyettesi állomány újólagos rendszeresítésére, akkor is alapvetóen az ilyen állománykategória fontosságának hangsúlyozása mellett a honvédség hasonló kezdeményezésére hivatkozva. ${ }^{16} \mathrm{~A}$ határórségre ebben az idóben jellemzó oda-vissza szervezés minden téren megmutatkozott, nem csak a személyzeti munkában, mérhetetlen károkat okozva. (Aknamezó telepítése 1949, felszedése 1956; Jugoszlávia a fóirány 1950, Ausztria a fóirány 1953; határövezet bevezetése 1951, határövezet megszüntetése 1956; hároméves sorkatonai szolgálat bevezetése 1950; 27 hónapos sorkatonai szolgálat elrendelése 1956.)

A megoldás következó változata a sorállomány igénybevétele tiszthelyettesi munkakörök ellátására. Ebben az idóben a kötelezô sorkatonai szolgálat már három év, egészen 1956 végéig, amikor a határórség átáll a 27 hónapos szolgálatra. A bevonulás elvileg november hónapban volt és egyidóben három egymást követô korosztály teljesített szolgálatot. A legtehetségesebbeket az alapkiképzést követóen a saját határốr tiszthelyettesi iskolára küldték Fótra (Zrínyi Miklós Tiszthelyettes Iskola). Ennek elvégzését követően általában szakaszvezetőnek, tizedesnek avatva kerültek be a határórségi vérkeringésbe, tiszthelyettesi munkakörökbe (ellentmondás, hogy a szakaszvezetói rendfokozat tisztesi rendfokozat, de viselói tiszthelyettesi feladatokat láttak el). Ez a felkészített katona viszont csak jó két évet dolgozott, majd leszerelt és visszatért a civil életbe. Nem válhatott olyan meghatározó személlyé, mint egy 10-15 évet szolgált hivatásos tiszthelyettes, annak ellenére, hogy becsületesen helyt álltak a gyakran igen nehéz körülmények között. Az iskolán általában egyszerre 400 fő tanult és a végzéskor ennyi munkakört lehetett betölteni. Ebból az állománycsoportból igyekeztek toborozni a továbbszolgáló kategóriába.

1951-ben a sor tiszthelyettes képzés, (tiszthelyettes tanfolyam) Fóton 1951. 03. 12-tól - 10. 14-ig tartott, és 426 fő végzett. ${ }^{17}$ A hét hónapos viszonylag hosszú idő színvonalas felkészítést tett lehetôvé. (A végzettek rendfokozati megoszlása a kibocsátáskor: államvédelmi sor ôrmester 21 fő, szakaszvezető 35 fő, tizedes 366 fő, ôrvezető 4 fő.)

A legfontosabb kérdés természetesen a tiszti állomány kiegészítése, pótlása lett. Az elsô időszakban a sorállományt és a meglévő tiszthelyettesi gárdát tekintették a legoptimálisabb forrásnak, vélhetóleg a meglévő határórizeti tapasztalataik miatt. A rövidített idejú tiszti tanfolyam erre a célra tökéletesen alkalmasnak túnt.

Az 1951. májusban megjelent országos parancsnoki parancs ${ }^{18}$ felvételt hirdetett tiszti tanfolyamon induló tanulmányokra. Hivatásos vagy továbbszolgáló tiszthelyettesek jelentkezhettek, csak azok, akik 1945 után végeztek tiszthelyettesi vagy

16 MNL HOP XIX-B-10 1957. év 23. sz. doboz VII/1. tárgykör, 49. folyószám. „Javaslat a hivatásos tiszthelyettesi állomány létrehozására". 1957. 05. 20.

17 NL HOP XIX-B-10 1951. év 1. sz. doboz, Államvédelmi Hatóság Határôrség és Belső Karhatalom Parancsnokának 090. sz. parancsa. 1951. 10. 13. Tiszthelyettes képzés befejezése.

18 MNL HOP XIX-B-10 1951. év 1. sz. doboz, Államvédelmi Hatóság Határórség és Belső Karhatalom Parancsnokának 038. sz. parancsa. 1951. 05. 09. Tisztképzó tanfolyam indítása. 
őrsparancsnoki tanfolyamot. A már tiszti iskolát vagy tiszti tanfolyamot végzetteket kizárták a jelentkezés lehetőségéból.

A meghirdetett feltételek, a pontok tartalmi sorrendje egybecseng a politikai elképzelésekkel. A szakmai alkalmasság a negyedik helyen szerepel:

1. politikailag felétlen megbízható legyen,

2. párttag, tagjelölt vagy DISZ tag,

3. szociális származása munkás vagy paraszt,

4. szakmai és fizikai rátermettség,

5. legalább hat elemi iskolai végzettség,

6. „KA” alkalmassági fok.

Decemberben már a tanfolyamon végzett tisztek avatása és elosztása történt. ${ }^{19} \mathrm{~A} 41$ fóból a túlnyomó többség alhadnagyi rendfokozattal került állományba. A képzést befejezettek névsorában szereplók közül egyesek 1956-57-ben már kerületparancsnoki, országos parancsnokság törzsfónöki, illetve osztályvezetôi beosztást töltöttek be, hihetetlenül gyors karrierrel.

A honvédségi tiszti iskolát végzettek is fontos forrásai lettek a pótlásnak. Szeptemberben intézkedtek az újonnan érkezók elosztására. ${ }^{20}$

Összesen 270 fő́ vonult be a tiszti iskolák elvégzését követốn z alábbiak szerint:

- Honvéd Dózsa Gyalogos Tisztképző Iskola 169 fó.

- Tüzértiszti Iskola 6 fó.

- Híradó Tiszti Iskola 24 fô.

- Hadtáp Tiszti Iskola 70 fó.

Ennél az évfolyamnál eredetileg minden résztvevót a határơrség legénységi állományából toborozták és vezényelték az iskolára.

\section{A hivatásos állomány stabilizálása}

Az elózóleg bemutatott viszonyokat megismerve felmerül a kérdés, mennyire sikerült a határôrségnek egy új hivatásos állományt kialakítani és azt stabilizálni? A személyzeti munka területén a következô válságidôszaknak az 1956-1957-es évek bizonyultak. Az ekkor történtek vizsgálata egy másik publikáció kereteit töltené ki, így csak az 1956. októberig terjedő időszakot értékelem.

1958 végén valamilyen számomra ismeretlen okból a határórség parancsnokságán visszamenóleg elemezték az 1950-1956 októbere előtti személyi mozgást, csak a tiszti állományra vonatkozóan. Az összegzésról egy rendkívül értékes, több következtetés levonására alkalmas anyag született. ${ }^{21} \mathrm{~A}$ parancsnokság fejrészét viseló, két példányos dokumentum 42 oldalon 814 nevet szerepeltet azokról, akik a határórségnél hivatásos tisztként szolgáltak, és még az októberi események előtt leszereltek,

19 MNL HOP XIX-B-10 1951. év 1. sz. doboz, Államvédelmi Hatóság Határőrség és Belsô Karhatalom Parancsnokának 0124. sz. parancsa. 1951. 12. 19. Tiszti továbbképző és tiszti tanfolyam befejezése.

20 MNL HOP XIX-B-10 1951. év 1. sz. doboz, Államvédelmi Hatóság Határőrség és Belső Karhatalom Parancsnokának 080. sz. parancsa. 1951. 09. 17. Tiszti iskolát végzettek fogadása.

21 MNL HOP XIX-B-10 11. sz. doboz 1958 év II/1-9. tárgykör 17. folyószám. „Névjegyzék az 1956 október 23-a előtt leszerelt tisztekról." 1958. 10. 18. 
az akkor történtek döntésüket nem befolyásolták. A nevek mellett szerepel a távozás éve és oka. A távozás jelzései: elbocsátás, fegyelmi út, létszámcsökkentés, saját kérésre.

1950-1956 között saját kérelemre 25 fő szerelt le. Fegyelmi úton jelzéssel 61 fő szerepel a listán.

Leszereltek évek szerint (814 név):

- 1950, 8 fö, nyilván nem teljes az adat.

- 1951, 88 fö.

- 1952, 126 fő.

- 1953, 96 fö.

- 1954, 241 fő (121 fô létszámcsökkentéssel).

- 1955, 96 fö.

- 1956, 159 fő. (52 fő létszámcsökkentéssel).

Összesen 814 fő szerepel a listán. Az 1950-es év a nagy „tisztogatás” éve, a megadott nyolc fő csak úgy lehet igaz, amennyiben valamilyen különleges ok miatt hagyta el a szervezetet. A már többször idézett jelentés '50. január és '51. február között 218 fó tiszt eltávolítását tartalmazza, akiket az '58-as névjegyzék nem említ. Ennyivel is növekszik a határôrségtól kikerült tisztek száma.

Több kérdést is kiemelhetünk az elózóekból:

- Hat év alatt a hivatásos tiszti állomány jó 80-90\%-a több hullámban távozott, ez nyilvánvalóan a pótlásuk szempontjából rendkívüli erófeszítéseket kívánt, illetve mutatja, a késóbbiekben egzisztenciálisan sem tudták megtartani az embereket.

- A korábbi túlméretezett határórségi fejlesztést, akárcsak a honvédségnél, leépítés követte. A lista szerint 1954-ben novemberben 121 fö (öt nap alatt), és 1956. januárban 52 fó (három nap alatt) szerelt le létszámcsökkentés miatt.

- Az 1956. januári leszerelések mutatják, hogy a határórség és a BM vezetése a jövőt illetôen (októberi robbanás) semmiféle sejtéssel sem rendelkezett. Ellenkezô esetben ragaszkodnak a létszámhoz, és felkészülnek egy amúgy sokat emlegetett belbiztonsági válsághelyzet kezelésére.

A leszereltek között van 27 fó százados, ez akkor igen magas rendfokozat volt, zászlóaljparancsnokok, alosztályvezetók. Tíz fő ôrnagy, ami a kerületparancsnoki, országos parancsnokság osztályvezetői szint. Érdemes megnézni az eltávozók beosztását:

- órsparancsnok 112 fó,

- politikai tiszt, többnyire örs vagy század politikai helyettes 148 fó,

- zászlóaljparancsnok 17 fö,

- forgalomellenórzó pont parancsnok 15 fó,

- századparancsnok 12 fő.

\section{Záró gondolatok}

A határôrség 1950. évi ÁVH alá rendelése egy egyre inkább szélsôséges irányba csúszó országos politika része volt. Szakmailag is olyan viszonyok alakultak ki, amelyeket nehéznek vagy lehetetlennek bizonyult teljesíteni. Határsávot és határövezetet állítottak fel; kiépült a múszaki zár az aknamezóvel; jelentôs létszámnövelést és 
szervezeti fejlesztést hajtottak végre; Jugoszlávia, a jugoszláv államhatár lett a határőrizet főiránya; a sorkatonai szolgálat idejét három évre növelték. Az elöljárói követelmény a déli és nyugati államhatár hézagmentes lezárása lett, amelyet azonban objektív okokból semmiképpen sem lehetett teljesíteni. Mindezek a hivatásos állományra rendkívüli terhet róttak.

Az egyik legsúlyosabb intézkedés a Honvéd Határórségnél szolgálatot ellátó hivatásos állomány többnyire vélt okok miatti eltávolítása lett. A kiesók pótlása, többnyire gyenge felkészültségú, rosszul kiképzett újonnan felvett kezdókkel tovább rontotta a határórizet hatékonyságát. A következó években sem sikerült stabilizálni az állományt, magas volt a szervezetet elhagyók száma. A személyzeti munkát nehezítette a folytonos átszervezés, a szervezet 1950-1951-es felduzzasztása és az 1954-es és 1956-os leépítés.

\section{FELHASZNÁLT FORRÁSOK ÉS IRODALOM}

Deák József 2015. A Belügyi Szemle és az ideológiai háború a helsinki konferenciáig 1953-1975. In Bencsik Péter, Boda József, Deák József, et. al. (szerk.): Ünnepi tanulmányok Gáspár László 65. születésnapja tiszteletére.

Budapest: Szemere Bertalan Magyar Rendvédelem-történeti Tudományos Társaság.

Deák József 2016. A rendészettudomány kialakulása és gondozásának nemzetbiztonsági, határốrizeti példái a Belügyi Szemlében a rendszerváltásig. Nemzetbiztonsági Szemle (online) 4. (4): 43-75.

Fórizs Sándor 2015. A határơrség megalakulása, valamint tevékenysége az elsô években (1945-1950). Magyar Rendészet XV. (6): 89-102.

Fórizs Sándor 2017. A határốrség megszervezése és múködése, 1945-1956.

In Pósán László, Veszprémy László, Boda József, Isaszegi János. (szerk.):

Órzók, vigyázzatok a határra! Határvédelem, határörizet, határvadászok a középkortól napjainkig.

555-608. Budapest: Zrínyi Kiadó.

MNL HOP XIX-B-10 1951. év, 9. sz. doboz II/2, II/3, II/5, II/6, II/9 tárgykör 1. folyószám. „Jelentés a Határơrség és Belső Karhatalom káderhelyzetéról. 1951 III. 5.-én".

MNL HOP XIX-B-10 1951. év, 1. sz. doboz II/2, II/3, II/5, II/6, II/9 tárgykör 1. folyószám. Államvédelmi Hatóság Határőrség és Belső Karhatalom Parancsnokának 01. sz. parancsa.1950. 01. 04. A tiszthelyettes állomány minősítése.

MNL HOP XIX-B-10 1951. év, 1. sz. doboz Államvédelmi Hatóság Határôrség és Belső Karhatalom Parancsnokának 019. sz. parancsa. Államvédelmi polgári alkalmazott állománycsoport létrehozása.

MNL HOP XIX-B-10 1957. év, 23. sz. doboz VII/1. tárgykör, 49. folyószám. „Javaslat a hivatásos tiszthelyettesi állomány létrehozására". 1957. 05. 20.

MNL HOP XIX-B-10 1951. év, 1. sz. doboz, Államvédelmi Hatóság Határôrség és Belső Karhatalom Parancsnokának 090. sz. parancsa. 1951. 10. 13. Tiszthelyettes képzés befejezése.

MNL HOP XIX-B-10 1951. év, 1. sz. doboz, Államvédelmi Hatóság Határőrség és Belső Karhatalom Parancsnokának 038. sz. parancsa. 1951. 05. 09. Tisztképzó tanfolyam indítása.

MNL HOP XIX-B-10 1951. év, 1. sz. doboz, Államvédelmi Hatóság Határőrség és Belső Karhatalom Parancsnokának 0124. sz. parancsa. 1951. 12. 19. Tiszti továbbképző és tiszti tanfolyam befejezése.

MNL HOP XIX-B-10 1951. év, 1. sz. doboz, Államvédelmi Hatóság Határőrség és Belsô Karhatalom Parancsnokának 080. sz. parancsa. 1951.09.17. Tiszti iskolát végzettek fogadása.

MNL HOP XIX-B-10 1958 év, 11. sz. doboz I/1-9. tárgykör 17. folyószám.

„Névjegyzék az 1956 október 23-a elótt leszerelt tisztekról." 1958. 10. 18. 